\title{
Papers
}

\section{Pension risk: Do employees care?}

Received (in revised form): 25th October, 2006

\begin{abstract}
Vrinda Gupta
is an economist at Watson Wyatt Worldwide, Delhi. Here she has been involved in research in diverse areas like offshoring, pension and compensation. Prior to joining Watson Wyatt in 2004, she was a Research Assistant at the Centre for Development Economics, Delhi School of Economics. Her research was focused on monetary policy transmission in the Indian economy. She obtained an M. Phil degree at Delhi School of Economics with her research area being agricultural exports and poverty.
\end{abstract}

\begin{abstract}
The literature shows that different market entities take into account the level of underfunding in the pension accounts while valuating firms. This paper analyses whether employees with a defined benefit pension scheme perceive risk to their expected income in retirement while forming their opinions about the long-term business success of their employer. Using a matched dataset of pension risk indicators for FTSE 100 companies and data from employees' opinion in the UK, the research shows that employees do seem to care about the level of funding of their benefits scheme when comparing their benefits with other companies and the industry average. But these concerns do not seem to affect their perception of the management or their confidence in business success and commitment to the firm.
\end{abstract} Pensions (2006) 12, 4-11. doi:10.1057/palgrave.pm.5950039

\section{Keywords: pension risk, market capitalisation, employee opinion}

\section{Introduction}

In the UK, company-sponsored pension plans have traditionally filled the gap left by state pensions and private savings. In the year 2004, the total membership of occupational pension schemes in the UK was $9.8 \mathrm{~m}$, with nearly 33 per cent of the employed having an occupational pension (Government Actuary Department, 2004 and World Development Indicators). ${ }^{1}$ The majority of active members (ie around 88 per cent) are covered by a defined benefit (DB) scheme (The 12th Survey by Government Actuary, UK, 2004 ${ }^{1}$ ). All public sector occupational pension schemes are DB and twothird of private occupational pension schemes are also DB. ${ }^{2}$ Currently, most of these DB schemes are managed as final salary schemes and many have traditionally invested a large proportion of their assets in equities.

In the wake of the stock market crash in the year 2001, increasing longevity and falling interest rates,

Correspondence: Vrinda Gupta,

2nd Floor, Golf View Towers A, Sector 42, DLF Phase 5, Gurgaon, India.

E-mail: vrinda.gupta@watsonwyatt.com. healthy pension surpluses for most of the FTSE 350 companies were turned into large deficits. In 2001 the pension deficit for FTSE 350 companies averaged $\delta 4.4 \mathrm{~m}$ while by year 2004 , the average had fallen to $\mathcal{E}^{254 \mathrm{~m}}$ (Watson Wyatt Pension Risk Indicators database). The average funding ratio of the pension schemes declined from 95 per cent in year 2001 to 79 per cent in year 2004 .

\section{Do employees care?}

Increasing longevity of the population in the UK coupled with stock market volatility has made final salary scheme unattractive and risky for employers. As a result, the majority of employers have closed down final salary schemes to new entrants (The 12th Survey by Government Actuary, UK, 2004 ${ }^{1}$ ). Other employers are diluting risk by encouraging workers to retire later and have increased the age at which the full retirement benefits starts accruing to the employees from 60 to 65 years.

Such changes in pension schemes have lead to unrest among workers in the UK, including industrial action by labour unions. In 2005 alone 
there were numerous strikes and threats over the issue of closing final salary scheme to new entrants and intentions to raise the age at which full benefits start accruing from 60 to 65 years. In October 2005, a mass walkout by public servants was averted when ministers abandoned their attempts to force health workers, teachers and civil servants to work till the age of 65 . In the same month, BP tanker drivers voted in favour of a strike to oppose the shift from final salary scheme to money purchase scheme. There was another threat of nationwide strike in December 2005 over the retention of 85-year rule. British Gas engineers went on strike in the same month to oppose the closure of their final salary scheme to new entrants. In January 2006, unions threatened the largest industrial action since 1926 over pension-related issues. Council workers and local government workers threatened to strike again in March 2006, while threat of national strike looms over the railways and Royal Mail. ${ }^{3}$

The question the author addresses is whether employees perceive the risks attached to their under-funded DB pension schemes given the increased deficit on the pension accounts. At the time of the survey there was an increased risk of companies defaulting on their pension promise.

In 2004, Watson Wyatt commissioned a survey of employees' opinions on their base pay, annual incentives and bonus; and how these compared with other employers. This survey also asked questions about their commitment to the organisation. The survey responses have been complemented with information regarding company financials and information on pension assets and liabilities.

The Watson Wyatt survey in 2004 covered employees from 130 companies; of these companies, 73 were FTSE 100 companies while the remainder were FTSE mid 250 companies. The pension deficit for FTSE 100 companies is higher. The median deficit in this group was E706m, while for the FTSE mid 250 companies the figure was $\ldots 108 \mathrm{~m}$.

In the survey, 70 per cent of employees have a DB pension scheme. Within this group, the majority of respondents (around 53 per cent) have experienced no changes to their pension

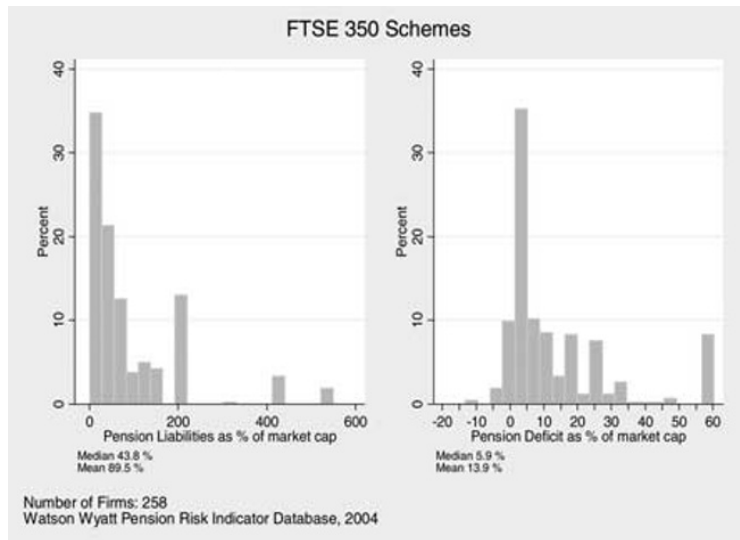

Figure 1: Pension risk in defined benefit scheme

rights in the last few years. Final salary schemes have closed for new entrants for 28 per cent of employees while retirement age has increased for three per cent of employees and benefits decreased for ten per cent of the employees.

The Watson Wyatt Pension Risk Indicators database (PRI) for FTSE 350 companies shows that the average pension liability is 47 per cent of market capitalisation as on June 2004, while the pension deficit as a percentage of market capitalisation is almost eight per cent. Looking at the distribution of pension liability across firms in the PRI database (2004) in Figure 1, one-fifth of the firms have pension liabilities surpassing their total market capitalisation. Although the absolute level of pension liabilities is high, the deficit on the pension accounts for companies is not as high, with half of the companies having pension deficit well within the range of five per cent of their market capitalisation.

The fact that a large number of companies have massive pension liabilities when compared with their market capitalisation implies that these companies are more likely to default on their obligation to provide for the retirement of their employees. Even companies with a smaller pension-deficit-to-market-capitalisation ratio also run a risk of defaulting on their obligations owing to large uncertainties regarding the return on pension assets, future salary increases and pension contributions, as well as general factors such as tax laws. 
The question is how different market entities perceive the risk attached to the pension accounts of the firms. Cardinale ${ }^{4}$ reviews the literature which shows that market valuation of firms take into account the level of underfunding in the pension accounts while valuating firms. The author quotes many studies where unfunded pension liabilities, retiree health liabilities and off-balance-sheet liabilities affect the stock market valuation of the companies. The author further constructs a model to show that even bond markets take into account the unfunded pension liabilities, and credit spreads are sensitive to pension liabilities as well. His model shows that the markets are more sensitive to underfunded than overfunded pension liabilities. The results also show that markets take into account factors affecting pension liabilities while valuing corporate debt but on the other hand they do not take into account the off-balancesheet liabilities in the pension accounts of the firms.

Given the existing evidence that bond and stock markets are sensitive to the pension liabilities of employers, this paper finds whether employees with a DB pension scheme perceive risk to their expected income in retirement owing to the unfunded pension liabilities piling up on their firms' balance sheets.

\section{Employee opinion}

When employees were asked 'How do the benefits your company provides you compare with elsewhere?', a larger proportion of the employees who were a part of pension schemes with larger pension deficits as a percentage of market capitalisation, felt that their pension benefits compared very poorly with other companies. In Figure 2 it can be noticed that 33 per cent of employees in the firms in the largest pension liability quintile, feel that their benefits do not compare well with other firms, while this figure doubles to 67 per cent for employees in the firms falling in the smallest pension liability quintile.

When the employees were asked to compare the extent of difference between their benefits package with the market average, a slightly larger proportion of employees who are

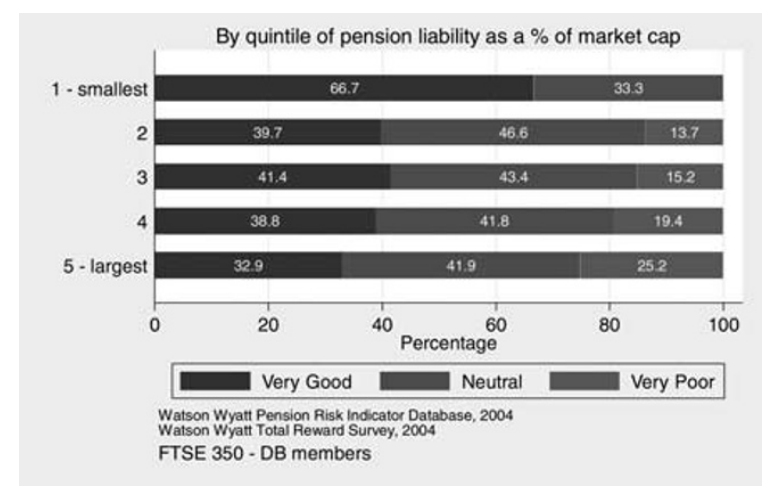

Figure 2: How do your pension benefits compare with elsewhere?

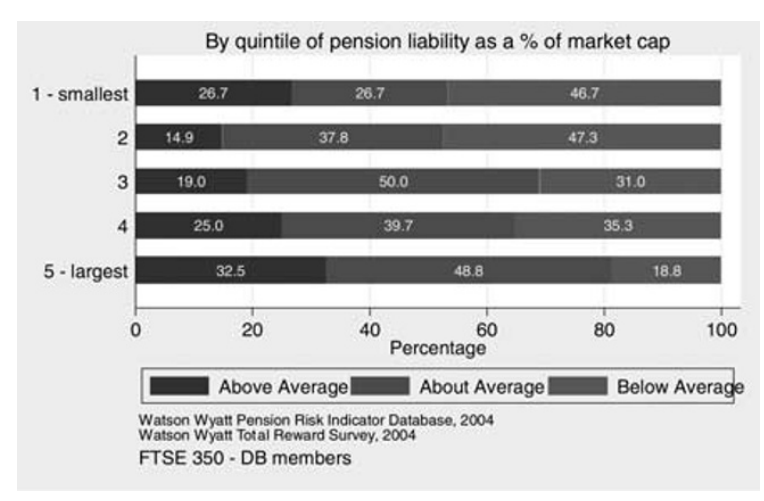

Figure 3: How do your pension benefits compare with the average?

members of more risky DB schemes, that is large pension liabilities as a percentage of market capitalisation, feel that their benefits are below average. In Figure 3, 33 per cent of employees in the firms with largest liabilities feel that their benefits are below average, while this figure is at 27 per cent for firms with the smallest liabilities. ${ }^{5}$

This dissatisfaction among the employees of firms with large pension liabilities can potentially be explained by a number of factors. It is possible that firms may be having large pension liabilities alongside benefits package that may not compare well with other firms. Or it may be the case that employees can perceive the risks attached to the high level of deficits attached to their pension 
Table 1: Benefits as compared to other firms

\begin{tabular}{|c|c|c|c|}
\hline $\begin{array}{l}\text { How do the benefits your company } \\
\text { provides you compare with elsewhere? }\end{array}$ & Model 1 & Model 2 & Model 3 \\
\hline Pension liabilities as $\%$ of market cap & & & $-0.002(2.81)^{\star *}$ \\
\hline Funding ratio (\%) & & $-0.001(0.09)$ & \\
\hline Pension deficit as $\%$ of market cap & $-0.011(2.63)^{\star \star}$ & & \\
\hline Log market cap & $0.046(0.94)$ & $0.044(0.91)$ & $0.010(0.2)$ \\
\hline Profitability & $0.225(0.38)$ & $0.596(0.83)$ & $0.371(0.51)$ \\
\hline Leverage & $0.075(1.54)$ & $0.041(0.84)$ & $0.091(1.77)$ \\
\hline $\begin{array}{l}\text { Company is good at providing information } \\
\text { on benefits }\end{array}$ & $0.764(5.40)^{\star \star}$ & $0.781(5.88)^{\star \star}$ & $0.770(5.78)^{\star \star *}$ \\
\hline Scheme closed to new members & $-0.232(1.86)$ & $-0.267(2.13)^{\star}$ & $-0.253(2.01)^{\star}$ \\
\hline Age & $-0.089(1.35)$ & $-0.080(1.16)$ & $-0.086(1.25)$ \\
\hline Females & $-0.033(0.2)$ & $-0.018(0.11)$ & $-0.055(0.34)$ \\
\hline Estimated mean log pay & $0.664(4.48)^{\star \star}$ & $0.651(4.58)^{\star \star}$ & $0.667(4.65)^{\star \star}$ \\
\hline Five-year TSR & $0.000(0.04)$ & $0.006(0.96)$ & $-0.004(0.54)$ \\
\hline Sector dummies & Yes & Yes & Yes \\
\hline Observations & 342 & 343 & 342 \\
\hline
\end{tabular}

Notes: Absolute value of $z$ statistics in parentheses, *Significant at $5 \%$; ${ }^{*}$ Significant at $1 \%$.

Source: Total Rewards Survey \& Pension Risk Indicators 2004, Watson Wyatt and author's calculations. All estimations are done on statistical software STATA. Bold explains the dependent variable significantly.

schemes. A regression model is run to examine the reasons for this observation.

The responses to the question 'How do the benefits your company provides you compare with elsewhere?' have been modelled using ordered probit regression techniques to test how far the level of funding of the pension scheme shapes responses. The results are reported in Table 1. There are three measures of pension risk: pension liability as a percentage of market capitalisation, pension deficit as a percentage of market capitalisation and the funding ratio. Positive numbers denote a more favourable perception of benefits. It is found that in all the models, employees with higher pay are more likely to feel that their benefits compare well with elsewhere. This is likely because in DB pension arrangements, employees with higher wages receive higher benefits or are members of more generous schemes. Also individuals who believe that their companies are doing a good job at providing information regarding their benefits are more likely to feel that their benefits compare well with other companies.

Furthermore, regressions show that the respondents perceive the risk attached to their pension scheme to some extent. In model 1, the employees working for firms with higher pension liabilities are more likely to feel that their benefits do not compare well with other places. In fact, the predicted probability of benefits comparing very well with other companies decreases by approximately 34 per cent when pension deficit as a percentage of market capitalisation increases from the minimum to the maximum.

When the respondents were asked to benchmark their benefits package to the industry average, a similar picture appears. Individuals who feel that their company is doing a good job at providing them with the benefits information are the ones who rate their benefits package well as compared to the average. Older respondents nearing the retirement age are more likely to feel that their benefits are below average as compared to the industry benchmark (Table 2).

As in the previous regression, pension liability as a percentage of market capitalisation plays an important role in shaping the perception of the respondents. Individuals working at firms with higher pension deficits are proportionately more likely to feel that their benefits are below industry average. The predicted probability of benefits comparing far below with the industry average increases by 27 per cent when pension liability as a percentage of market capitalisation increases from minimum to maximum.

Similar results are obtained when pension risk is measured by pension deficit as a percentage of market capitalisations. On the other hand, funding ratio does not give significant results. This 
Table 2: Benefits as compared to the industry average

\begin{tabular}{|c|c|c|c|}
\hline $\begin{array}{l}\text { How do you think your benefits package compares with the } \\
\text { benefits offered by other similar firms on average? }\end{array}$ & Model 1 & Model 2 & Model 3 \\
\hline Pension liabilities as $\%$ of market cap & & & $-0.001(1.88)$ \\
\hline Funding ratio (\%) & & $0.003(0.47)$ & \\
\hline Pension deficit as $\%$ of market cap & $-0.018(3.94)^{\star \star}$ & & \\
\hline Log market cap & $0.056(1.11)$ & $0.048(0.98)$ & $0.024(0.48)$ \\
\hline Profitability - profits over sales & $-0.057(0.08)$ & $0.388(0.53)$ & $0.249(0.34)$ \\
\hline Leverage & $0.030(0.53)$ & $-0.010(0.21)$ & $0.024(0.47)$ \\
\hline Company is good at providing information on benefits & $0.932(6.57)^{\star \star}$ & $0.930(6.86)^{\star \star}$ & $0.920(6.77)^{\star *}$ \\
\hline Scheme closed to new members & $-0.105(0.8)$ & $-0.174(1.39)$ & $-0.165(1.32)$ \\
\hline Age & $-0.198(2.95)^{\star \star}$ & $-0.181(2.61)^{\star \star}$ & $-0.184(2.65)^{\star \star}$ \\
\hline Female & $-0.180(1.23)$ & $-0.170(1.03)$ & $-0.196(1.19)$ \\
\hline Estimated mean log pay & $0.168(1.29)$ & $0.115(0.84)$ & $0.133(0.97)$ \\
\hline Five-year TSR & $-0.008(1.16)$ & $0.001(0.21)$ & $-0.006(0.85)$ \\
\hline Sector dummies & Yes & Yes & Yes \\
\hline Observations & 348 & 349 & 348 \\
\hline
\end{tabular}

Notes: Absolute value of $z$ statistics in parentheses, *Significant at $5 \%$; ${ }^{\star}$ Significant at $1 \%$.

Source: Total Rewards Survey \& Pension Risk Indicators 2004, Watson Wyatt and author's calculations. All estimations are done on statistical software STATA. Bold explains the dependent variable significantly.

regression model was estimated with five quintiles of each of the pension risk variable. The results were significant for pension liability as a percentage of market capitalisation only.

\section{Pension funding and employees' trust and confidence in the management and commitment to workplace}

From the analysis in the previous section, it is apparent that some employees perceive the risk attached to their pension schemes while ranking their benefits package vis-à-vis other similar firms and industry averages. Do these perceptions impact employees' confidence in the long-term success of the firm?

The survey asks respondents whether they strongly agree, agree, disagree or strongly disagree with the statement 'I have confidence in the longterm success of my company'. The graph below shows that individuals who are a part of pension schemes with lower pension liability as a percentage of market capitalisation tend to report higher confidence in the long-term success of the firm (Figure 4). ${ }^{6}$

Employees' trust and confidence in the senior management of the company does not seem to vary significantly with the level of pension deficits as a percentage of market capitalisation. When employees were asked to rate this statement, 26

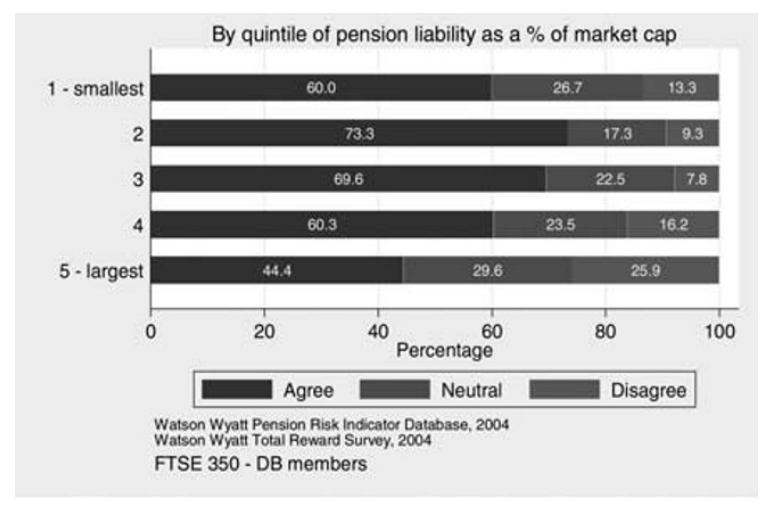

Figure 4: Confidence in long-term success of my company

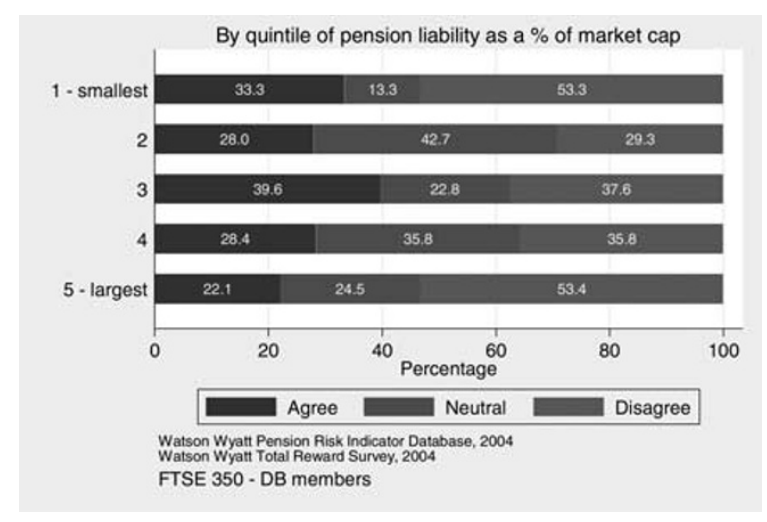

Figure 5: Trust and confidence in senior management

per cent of respondents who are members of high-risk pension schemes did not have confidence in their company's senior management 
while this figure was 13 per cent for low-risk pension schemes (Figure 5).

The respondents were further asked whether they would recommend their company as a good place to work, in order to gauge their commitment towards the company. Thirty-three per cent of the members of less risky pension schemes reported trust and confidence in the long-term success of the company; this percentage is not much lower at 22 per cent for high-risk pension schemes. In Figure 6 also, it is seen that the percentage of people who would recommend their company as a good place to work does not vary by the size of pension risk attached to the schemes. ${ }^{7}$

The above three graphs do not give a clear picture regarding the importance of the level of underfunding in the pension schemes in defining employee trust, confidence and commitment. Risks attached to the pension scheme seem to affect employees' confidence in the long-term success of the business but the relationship with their level of commitment and trust in senior management does not seem to be related to the risk attached to the pension schemes.

It is possible that other, overriding reasons will dilute the above-mentioned relationships. Employees may perceive the success of the senior management of the company to be driven by the performance of an industrial sector rather than the level of pension deficits in the company accounts. Or employees would recommend their company as a good place to work despite the significant pension liabilities

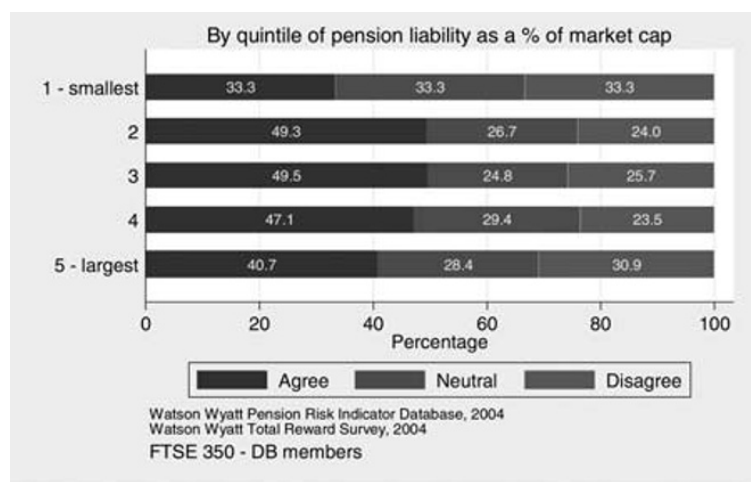

Figure 6: I would recommend my company as a good place to work because the company may offer other more lucrative incentives to its employees, so that this risk is attenuated.

In order to ascertain the importance of risks attached to the pension deficit in shaping employee trust, confidence and commitment, all these have been modelled as a function of pension deficit and funding ratio as well as other variables such as company performance and employee characteristics.

Table 3 shows that risks attached to the pension schemes do not have a significant association with employee trust, confidence and commitment. It is rather the company performance, that is total shareholder return in the last five years and market capitalisation that has a significant and positive relationship with workers' trust in senior management. Also, companies doing a good job at providing benefits are generally high on employee trust. Further employee characteristics like age and pay also play an important role, with older employees generally having lower level of trust in the management while employees drawing a higher salary tending to trust their senior management more than those with lower salaries. Also when employees feel that the company does a good job at providing benefits information, they seem to trust senior management.

Investigating the relationship between confidence in the long-term business performance and pension risk, the regression equations show that company performance, whether it is doing a good job at providing benefits information or have a positive and a significant association with the dependent variable. As in the previous regression results, older workers have less confidence in the long-term business success.

Commitment to the company is also associated with similar variables. Corporate performance variables like shareholder return, profitability and quality of information regarding benefits play an important role here. While older workers are less likely to recommend their company as a good place to work, those in higher pay bracket are more likely to do so. Here again the pension risk variables are not significantly associated with the dependent variable. 
Table 3: Trust, confidence and commitment to the employer

\begin{tabular}{|c|c|c|c|c|c|c|}
\hline & \multicolumn{2}{|c|}{$\begin{array}{l}\text { I have trust and confidence in the } \\
\text { job being done by the senior } \\
\text { management }\end{array}$} & \multicolumn{2}{|c|}{$\begin{array}{l}\text { I have confidence in the } \\
\text { long-term business success } \\
\text { of my company }\end{array}$} & \multicolumn{2}{|c|}{$\begin{array}{l}\text { I would recommend my company } \\
\text { to others as a good place to work }\end{array}$} \\
\hline & Model 1 & Model 2 & Model 1 & Model 2 & Model 1 & Model 2 \\
\hline $\begin{array}{l}\text { Pension deficit } \\
\text { as \% of market } \\
\text { cap }\end{array}$ & $-0.001(0.96)$ & & $-0.004(0.89)$ & & $0.003(0.73)$ & \\
\hline $\begin{array}{l}\text { Pension liability } \\
\text { as \% of market } \\
\text { cap }\end{array}$ & & $0.002(0.53)$ & 0.000 & $-0.001(0.92)$ & & $0.000(0.11)$ \\
\hline Log market cap & $-0.117(2.36)^{\star}$ & $-0.106(2.22)^{*}$ & $-0.012(0.25)$ & $-0.025(0.5)$ & $-0.119(2.77)^{\star \star}$ & $-0.120(2.69)^{\star \star}$ \\
\hline $\begin{array}{l}\text { Profitability } \\
\text { - profits over } \\
\text { sales }\end{array}$ & $0.543(0.77)$ & $0.609(0.85)$ & $0.865(1.14)$ & 0.917 (1.21) & $1.592(2.68)^{\star *}$ & $1.531(2.58)^{\star \star}$ \\
\hline Leverage & $0.001(0.01)$ & $-0.015(0.28)$ & $0.027(0.6)$ & $0.033(0.71)$ & $-0.013(0.31)$ & $-0.007(0.16)$ \\
\hline $\begin{array}{l}\text { Company } \\
\text { is good at } \\
\text { providing info } \\
\text { on benefits }\end{array}$ & $0.712(5.33)^{\star *}$ & $0.719(5.38)^{\star *}$ & $0.864(6.70)^{\star \star}$ & $0.863(6.68)^{\star \star}$ & $0.977(7.41)^{\star \star}$ & $0.973(7.37)^{\star \star}$ \\
\hline $\begin{array}{l}\text { Scheme } \\
\text { change: } \\
\text { Scheme } \\
\text { closed to new } \\
\text { members }\end{array}$ & $-0.122(0.97)$ & $-0.138(1.09)$ & $-0.206(1.6)$ & $-0.215(1.7)$ & $-0.196(1.57)$ & $-0.181(1.48)$ \\
\hline Age & $-0.219(3.19)^{\star \star}$ & $-0.218(3.15)^{\star \star}$ & $-0.180(2.61)^{\star \star}$ & $-0.178(2.63)^{\star *}$ & $-0.197(3.15)^{\star *}$ & $-0.199(3.19)^{\star \star}$ \\
\hline Females & $-0.165(0.96)$ & $-0.16(0.92)$ & $-0.272(1.64)$ & $-0.278(1.68)$ & $-0.179(1.1)$ & $-0.178(1.1)$ \\
\hline $\begin{array}{l}\text { Estimated mean } \\
\text { log pay }\end{array}$ & $0.406(2.63)^{\star \star}$ & $0.387(2.49)^{\star}$ & $0.048(0.34)$ & $0.049(0.35)$ & $0.372(2.63)^{\star *}$ & $0.383(2.69)^{\star \star}$ \\
\hline Five-year TSR & 0.009 (1.34) & $0.013(2.25)^{*}$ & $0.020(3.05)^{\star \star}$ & $0.019(2.55)^{\star}$ & $0.003(0.5)$ & $0.001(0.18)$ \\
\hline $\begin{array}{l}\text { Sector } \\
\text { dummies }\end{array}$ & Yes & Yes & Yes & Yes & Yes & Yes \\
\hline Observations & 351 & 351 & 351 & 351 & 351 & 351 \\
\hline
\end{tabular}

Notes: Absolute value of $z$ statistics in parentheses, ${ }^{*}$ Significant at $5 \%$; ${ }^{\star *}$ Significant at $1 \%$. ${ }^{[2]}$ Source: Total Rewards Survey 8 Pension Risk Indicators 2004, Watson Wyatt and author's calculations. All estimations are done on statistical software STATA. Bold explains the dependent variable significantly.

This insignificant association of magnitude of pension liabilities and underfunding of pension schemes with trust in management, confidence in business success and commitment to firm may be a result of various factors. For example, employees who care about the level of underfunding of the pension schemes may have already left for the companies with better funded pension accounts (worker selection) or employees are being paid more in order to make up for the risk they bear by being a part of a risky pension scheme (compensating differentials). But these reasons are seen as less persuasive.

There is a large literature that deals with the issue of trade-off between wages and pension. This strand of literature looks at the possibility that employers may be paying higher wages in order to compensate for the less generous pension scheme. Gunderson et al. ${ }^{8}$ provide a brief review of this literature and conclude that the evidence on the presence of such a trade-off is ambiguous. There is no evidence that shows that individuals would prefer to be part of a better funded pension plan. This leaves scope for further research regarding the impact of pension underfunding on job mobility and pay.

Another factor that could explain this insignificant relationship between pension risk and employee trust, confidence and commitment may be that issues other than pensions are more important in shaping employees' perception. Or, of course, employees may simply not have an idea of the extent of pension risk involved in their pension schemes.

\section{Conclusion}

There has been unrest among workers in the UK on pension issues such as closing of DB pension 
schemes to new entrants, raising the retirement age and reducing benefits. These changes are being put to practice to address costs and risks associated with underfunded DB pension schemes. The question addressed here is whether employees care about the risk attached to their DB pension schemes? Employees do seem to care about the level of funding of their benefits scheme when comparing their benefits with other companies and the industry average. But these do not seem to affect their perception of the management or their confidence in business success and commitment to the firm.

\section{Acknowledgments}

The author would like to thank Jonathan Gardner, Mirko Cardinale, Mike Orszag and anonymous referee for their invaluable comments.

\section{References and Notes}

1 Government Actuary (2004) 'Occupational Pension Schemes 2004 - The Twelfth survey by government actuary.
2 Many DB schemes are closed to new entrants, who generally have access to a defined contribution (DC) scheme instead.

3 Source: Online edition of The Guardian: http://politics.guardian. co.uk/unions/0,,747421,00.html.

4 Cardinale, M. (2006) 'Corporate Pension Funding and Credit Spreads', Watson Wyatt Technical Papers.

5 The Pearson's chi-square statistic for Figures 1 and 2 is significant at ten per cent level of significance. This proves that there is association between the quintiles of pension risk and benefits. Hence, it can be concluded that the percentage of individuals with poor benefits tend to be a part of more risky pension schemes.

6 These differences in the opinion across quintiles of pension risk are significant as the Pearson's chi-square measure of association indicates a significant association between pension risk and confidence.

7 The Pearson's chi-square measure of association shows that trust and confidence in senior management and commitment (recommend work place to friends) does not vary significantly with pension risk. Hence, it can be concluded that trust and commitment do not depend on pension risk.

8 Gunderson, M., Hyatt, D. and Pensando, J. E. (1992) 'Wagepension trade offs in collective agreements', Industrial and Labour Relations Review, Vol. 46, No. 1, pp. 146-160. 